\title{
As comemorações do centenário da imigração alemã no contexto do pós Primeira Guerra Mundial
}

\author{
The celebrations of centenary of german immigration in the First World War's context
}
Las conmemoraciones del centenario de la inmigración alemana en el contexto de pos
Primera Guerra Mundial

\author{
Roswithia Weber* \\ Eloisa Helena Capovilla da Luz Ramos*
}

\section{Resumo}

O presente artigo enfoca as comemorações do Centenário da imigração alemã no Rio Grande do Sul, mais especificamente, em São Leopoldo, considerando o contexto do Pós-Primeira Guerra Mundial e dos resquícios do "Perigo Alemão". Por de pesquisa documental analisa discursos proferidos nos ritos comemorativos ao Centenário da imigração alemã. Identifica, nesses ritos, que a presença da "pátria-mãe" Alemanha, não se efetiva somente em lembranças remotas dos primeiros imigrantes, mas também considerando a Alemanha do pós-guerra.

Palavras-chave: Centenário da imigração alemã. Primeira Guerra Mundial. São Leopoldo.
* Graduada em História pela Universidade do Vale do Rio dos Sinos (1996), mestrado em História pela Universidade Federal do Rio Grande do Sul (2000) e doutorado em História pela Universidade Federal do Rio Grande do Sul (2006). Atualmente é professora da Universidade Feevale (Novo Hamburgo/RS), atuando nos cursos de História e Turismo. E professora pesquisadora no Grupo de Pesquisa Cultura e Memória da Comunidade. Desenvolve pesquisas com ênfase em História Regional do Brasil, tematizando processos de construção de identidades locais; identidade étnica e relações interétnicas; identidade e turismo. Enfoca especialmente regiões de imigração alemã. É membro do Comitê de Etica em Pesquisa CEP Feevale, vinculado nacionalmente à Comissão Nacional de Ética em Pesquisa (Conep). Integra, também, o Instituto Histórico de São Leopoldo/RS. E-mail: roswithia@uol.com.br

* Graduada em História pela Universidade do Vale do Rio dos Sinos (1978), mestrado em História pela Universidade Federal do Rio Grande do Sul (1990) e doutorado em História pela Universidade Federal do Rio Grande do Sul (2000), com a tese "O teatro da sociabilidade: os clubes sociais como espaços de representação das elites urbanas alemãs e teuto-brasileiras - São Leopoldo: 1858 - 1930”. Atualmente, é professor Adjunto II da Universidade do Vale do Rio dos Sinos. Tem experiência na área de História, com ênfase em História Regional, do Brasil e do Cone Sul, atuando na linha de pesquisa Migrações, Territórios e Grupos Étnicos. Trabalha com temas relacionados à imigração no Rio Grande do Sul, no Brasil e nos países do Cone Sul, entre os quais se destacam: cidades e sociabilidades; memória, identidade e representação na/da e/imigração; patrimônio cultural imigrante. E-mail: loisa@unisinos.br

Recebido em 28/02/2014 - Aprovado em 30/07/2014 http://dx.doi.org/10.5335/hdtv.14n.2.4577 


\section{Considerações iniciais}

Em 1924, foi comemorado no Rio Grande do Sul o Centenário da imigração alemã. Em 25 de Julho de 1824, lá chegou a primeira leva de imigrantes alemães na então fundada Colônia de São Leopoldo. A partir de 1924, as comemorações desse acontecimento se proliferaram a cada ano, não só na cidade de São Leopoldo, localizada ao norte de Porto Alegre, capital do estado, mas também em várias regiões desse. Esse aspecto indica que a própria comemoração se constitui lugar de memória (NORA, 1993).

O presente artigo analisa como o conflito mundial eclodido em 1914 foi pauta dos discursos proferidos nos ritos comemorativos ao Centenário da imigração alemã, uma vez que, esses ocorram cinco anos após o término da guerra.

Serão enfocadas especialmente as festividades ocorridas em São Leopoldo, em espaços públicos e privados. Tomou-se como fonte a imprensa jornalística, periódicos locais e regionais que cobriram as comemorações. Outra fonte importante, nesse sentido, foi o livro organizado por Eduardo Duarte, O centenário da colonização alemã no Rio Grande do Sul: 1824-1924, publicado em 1946. Duarte acompanhou os festejos realizados em São Leopoldo, na condição de secretário do Arquivo Público do Estado e membro do Instituto Histórico e Geográfico do Rio Grande do Sul, organizando exposição histórica sobre o tema e participando de eventos, inclusive discursando em vários momentos. Nessa obra, o autor reúne informações sobre eventos do centenário da imigração alemã realizados em diferentes municípios do Rio Grande do Sul, publicados na imprensa, sendo que os discursos proferidos por ocasião dos festejos oficiais do estado que ocorreram em São Leopoldo, também a integram.

Os discursos e pronunciamentos são analisados, não como mero acesso ao conhecimento, mas a partir da compreensão de que ele próprio se constitui em um acontecimento, uma vez que está carregado de sentido (ALBUQUERQUE JÚNIOR, 2009; ORLANDI, 1996).

Dentre as fontes bibliográficas importantes para o estudo destaca-se: Gertz (1987, 1991, 2002) com seus estudos sobre o Perigo alemão e sobre a história das regiões de colonização alemã e, Ramos (2000) e Weber (2004) que enfocaram as comemorações do Centenário da imigração alemã.

\section{0 contexto expresso nos discursos das comemoraçoes do centenário}

As festas oficiais do estado tiveram como palco o município de São Leopoldo, dado que foi lá que se estabeleceram os primeiros imigrantes. A comissão dos festejos avaliou que comemorar o marco 25 de julho, nesse mês, não seria apropriado, devido às chuvas e ao frio do inverno. Assim, os festejos oficiais foram programadas para o mês de setembro.

As comemorações não eram momento de apenas mostrar o progresso desse município, era também hora de voltar-se ao passado, de ativar a memória (WEBER, 2004). Nesse sentido, a conjuntura do fim da Primeira Guerra Mundial e da política de nacionalização se mostrava oportuna. Após a 
"experiência da derrota", ${ }^{1}$ e de um momento de proibições e boicotes, os descendentes de alemães e imigrantes viviam a oportunidade de comemorar a si próprios.

Paralelamente à exaltação do passado e do bom êxito da imigração alemã, pairava no ar resquícios de sentimentos anti-alemão ou de suspeitas com relação à assimilação. Isso pode ser compreendido dentro do espectro de um período em que se teve presente a campanha do "perigo alemão". Essa, conforme Gertz (2002) foi intensa no período anterior à Primeira Guerra mundial, cresceu em seu período inicial, e, embora tenha perdido força com a perda da guerra pela Alemanha, continuou presente no pós-guerra, se reascendendo com o nazismo.

Muitos discursos proferidos nas comemorações oficiais realizadas em setembro no município de São Leopoldo, tematizaram esse cenário. Num evento realizado na Praça Centenário, Olivério de Deus Vieira Filho falou em nome do município de Porto Alegre. Seu discurso teve um tom pedagógico, se posicionou como descendente de portugueses, dirigindo seu discurso aos "alemães":

É certo (...) que vós não abandonais o culto pela pátria de vossos ancestrais, como a grande maioria do povo brasileiro ainda não cessou de cultuar a pátria dos seus avoengos (...).

Daí, porque, vós que, nas vossas relações externas, usais o idioma vernáculo, no vosso interior, no trato familiar, vos expressais na língua dos vossos maiores (DUARTE, 1946, p. 165-166).

Olivério tratou de amenizar as críticas aos descendentes de alemães. A continuidade do discurso evidencia o tom disciplinador: "Pode variar a língua, mas isso que importa, se o dever é imutável e o vosso dever vos ordena que ameis a vossa Pátria, o Brasil, acima de todas as cousas" (DUARTE, 1946, p. 166). Terminou seu discurso ressaltando que não só a Alemanha tem heróis, mas também o Brasil. Pode-se notar que as comemorações não estiveram alheias às discussões políticas nacionais relativas à identidade nacional.

Assim, os festejos não foram um refúgio num passado distante, a evocação do passado teve raízes bem sólidas no presente, de forma que as motivações simbólicas funcionaram ativamente em seus diferentes momentos.

No contexto do país, o ano de 1924 marcou uma nova etapa da presença dos imigrantes e descendentes de alemães no Brasil. Nesse ano, segundo Gertz (1987), iniciaram movimentos para reverter a situação criada pela guerra na opinião pública nacional. Esse fator também deve ser considerado ao analisar as comemorações do Centenário da imigração alemã.

O clima festivo envolveu de alguma forma os segmentos de origem alemã que sofreram um "efeito de destilação", 3 pois mesmo que a opção de alguns tenha sido a de alinhamento à política de nacionalização, ou mesmo a não manifestação de preferências em público, as festas ofereciam uma gama de motivos para participar, suas multifuncionalidades, as diferentes formas delas serem vivenciadas, as contrariedades presentes em vários momentos, ampliam as possibilidades de interpretações (WEBER, 2004).

Analisando os ritos festivos do Centenário, é mister que se apontem algumas questões de fundo nos discursos proferidos. Esses 
podem ser divididos em temas. Um deles é o do agradecimento. Os discursos foram unânimes nesse aspecto. Agradecer a Deus por ter conduzido sãos e salvos ao Brasil e ao Rio Grande do Sul homens e mulheres alemães que aqui vieram em busca de uma vida melhor, onde se incluía terra e trabalho. Agradecer ao Brasil e ao Imperador D. Pedro I por ter oportunizado essa vinda, assim como ao Visconde de São Leopoldo, por ter acreditado nesse projeto. Agradecimentos também foram feitos aos pioneiros que permitiram o crescimento de seus descendentes com o seu trabalho inicial. Houve ainda discursos de louvação aos alemães que souberam crescer pelo seu trabalho. A frase "somos descendentes de trabalhadores e construtores alemães, cujo trabalho foi continuado por seus descendentes até a nossa geração", destaca-se pelas palavras trabalhadores e construtores. É assim que os teuto-brasileiros se veem nesse momento. Ao lado da palavra trabalho, outra toma vulto. É a fidelidade, que transparece em todas as falas desse evento. Fidelidade refere-se principalmente aos governantes, ao Brasil e ao Rio Grande do Sul. É preciso atentar para o fato de que o processo de nacionalização era muito recente e que por ele, os descendentes de alemães foram cobrados justamente em sua fidelidade, já que o "perigo alemão" foi apontado como uma ameaça à integridade do Brasil (RAMOS, 2000).

Então a tônica nessa palavra-chave teve um significado especial. A fidelidade, por seu turno, era o caminho para a prosperidade. Trabalho e progresso era uma espécie de slogan, um qualificativo que os alemães e seus descendentes se haviam outorgado, e que, embora construído, lhes fica- va bem, especialmente nos anos 20, quando estavam em ascensão econômica. Os discursos podem ser medidos também pela fala de reconhecimento por parte das autoridades regionais, da importância do trabalho alemão para o desenvolvimento do Estado, que fora transformado "de uma selva, ontem, para uma cidade, hoje" (RAMOS, 2000).

Frente à regularidade dos discursos que abrangeram os temas acima referidos, se observou a singularidade da Alemanha ser referida considerando o contexto do pós Primeira Guerra Mundial. Nesse sentido, deve-se considerar as estratégias de elaboração dos discursos:

Trata-se de não simplesmente considerar o discurso como a obra de um indivíduo isolado ou como mero reflexo do que lhe é exterior, mas de perguntar pelas regularidades que se podem mapear entre os discursos [...] (ALBUQUERQUE JÚNIOR, 2009, p. 238).

As comemorações do Centenário não podem ser compreendidas sem levarmos em conta os inúmeros discursos que foram proferidos em seus diferentes momentos. Contudo, a reconstrução do repertório temático não é suficiente para dar conta das complexas características da linguagem. ${ }^{4}$

\section{A germanidade e as comemorações do centenário}

Mesmo que a decisão de comemorar oficialmente o centenário ficasse para setembro, houve comemorações no próprio 25 de julho de 1924. O jornal Deutsche Post e a Sociedade Ginástica, instituições de São Leopoldo, associaram-se para a realização des- 
sas. Cabe observar, que a decisão de marcar o 25 de julho não se tratou de uma oposição às programações do 20 de setembro, pois ambas instituições participaram intensamente do processo de "construção" da festa, e contaram com o apoio da população local.

A Deutsche Post consistia num jornal de língua alemã de propriedade de Wilhelm Rotermund. Esse veio para São Leopoldo em 1874 para exercer a função de pastor da comunidade evangélica de São Leopoldo, ocupou esse posto até 1918. Tanto em sua atividade como pastor, quanto como jornalista teve posições bem marcadas com relação à defesa e ao fortalecimento da germanidade (DREHER, 1984; GERTZ, 2002). Em 1880, criou o jornal Deutsche Post e por meio desse divulgou entusiasticamente as comemorações do centenário da imigração alemã. Cabe ressaltar, que, no contexto dessas, quem estava à frente da direção do jornal era Ernesto Rotermund, filho de Wilhelm Rotermund.

A Sociedade Ginástica Leopoldense teve atuação efetiva durante os festejos do Centenário, tendo a frente de sua direção, Martin Fischer, doutor em direito que atuou na Primeira Guerra como capitão do Exército alemão (GERTZ, 2002).

Cabe observar que essa sociedade apresentou resistências às ações nacionalizadoras do governo do intendente Gabriel de Azambuja Fortuna, tanto que preferiu fechar as portas de sua sede social em 1917, para não deixar de falar o alemão. Fortuna ficou por três anos no governo, entre 1916 e 1919 e promoveu medidas nacionalizadoras que afetaram o funcionamento de clubes sociais locais. Nesse momento, as ações do governo brasileiro em relação aos alemães e/ou seus descendentes, os teuto-brasileiros, foi com o intuito de abrasileirá-los. Em 1921, quando a Guerra já havia acabado e o clube foi reaberto, o alemão era, novamente, o idioma oficial dos ginasticanos. Diferentemente, a nacionalização teve reflexos nos Clubes de Tiro de São Leopoldo, que desapareceram, ${ }^{5}$ e a Sociedade Orpheu, que se nacionalizou, e que eram parceiros da Sociedade Ginástica na manutenção da memória alemã (RAMOS, 2000).

Ambas instituições, Deutsche Post e Ginástica, são consideradas como propagadoras da germanidade. Nesse sentido, convém ter-se em vista a necessidade de distinguir as diferentes formas de alemães e descendentes manifestarem-se etnicamente. As comemorações do Centenário são expressão da etnicidade alemã. Essa sofreu modificações ao longo do tempo e apresentou diversas faces num mesmo momento. Uma das formas de imigrantes e descendentes de alemães afirmarem sua identidade foi por meio da adesão ao Deutschtum, traduzido como germanidade. Essa consiste numa etnicidade peculiar que foi formalizada no Século XIX e ancorada no nacionalismo alemão. Conforme Seyferth,

A concepção de uma germanidade teuto-brasileira (significado mais próximo, em português, da palavra Deutschbrasilianertum) está vinculada à idéia do pertencimento nacional pelo direito de sangue [...]. [...] Deutschbrasilianertum, como ideologia étnica, traz consigo uma inequívoca proposta de pluralismo étnico-cultural cada grupo de imigrantes com direito de manter seus costumes, cultura e língua, e todos igualmente cidadãos brasileiros (SEYFERTH, 1994, p. 18).

Assim, divulgadores da germanidade defendiam, no todo ou parcialmente, a pre- 
servação do idioma, das instituições, dos costumes e tradições. No processo de demarcação étnica, pesavam, portanto indicadores culturais como idioma e descendência comum. Essa última integrou o ideário de superioridade racial, acionado também para estereotipar o imigrante alemão como trabalhador (SEYFERTH, 1982).

Gertz (1987) faz referência à germanidade como fruto de uma difusão consciente que tinha a não assimilação como proposta central. Várias são as peculiaridades em torno da germanidade. Sua difusão no Século $X X$, ainda conforme o referido autor, se deu em diferentes graus.

Em São Leopoldo, o dia 25 de julho foi proclamado como feriado local. A Deutsche Post se empenhou em divulgar as comemorações:

[...] se encontrem à tarde ou à noite, para que vocês sintam a força da ligação de todos, como no início: nós somos alemães! E reconheçam-se, com o coração aquecido no mais profundo da alma, no seu povo alemão. Mostrem a todos os outros povos descendentes, em conjunto [...] que vocês se orgulham de ser descendentes de alemães, ter sangue alemão, ser de alma alemã. E renovem o juramento dos pais [...] de servirem com fidelidade alemã e dedicação alemã, até a última gota de sangue, ao seu Brasil, à terra que se tornou sua casa, pela qual, em resposta, seu coração bate em amor. ${ }^{6}$

Esse convite aparece nitidamente como expressão da germanidade, em acordo com o órgão de divulgação A noção de Deutschbrasilianer, que consiste numa proposta de pluralismo étnico-cultural em que cada grupo de imigrantes têm o direito de manter seus costumes e ao mesmo tempo serem cidadãos brasileiros (SEYFERTH, 1984), bem como a noção de Heimat, estão implica- das no convite. Esse último conceito "inclui os dois princípios que marcam a identidade teuto-brasileira: a origem étnica alemã, vinculada ao direito de sangue, e a nacionalidade/cidadania brasileira, com seu princípio territorial" (SEYFERTH, 1994, p. 19). Assim, expressam fidelidade ao Brasil, ao mesmo tempo em que se colocavam primeiro como alemães, com "orgulho de ser alemães".

A análise de discurso permite identificar que o locutor (Deutsche Post) se identifica ao seu alocutório (o público descendente de alemães). ${ }^{7}$ Esse tipo de discurso foi muito comum por ocasião dos festejos do Centenário, especialmente nos festejos de julho.

$\mathrm{O}$ "mito das origens" foi frequentemente evocado por ocasião das comemorações. Pesavento caracteriza este mito como:

[...] uma tendência imemorial, presente em todas as sociedades, de indagação sobre o passado. A busca de pai mítico e da gênese da identidade local é, pois, um elemento recorrente que parece responder a necessidades telúricas e ancestrais de toda comunidade (PESAVENTO,1993, p. 386).

O mito fundador local, ou seja, de São Leopoldo, baseou-se na construção de uma "mãe-mítica", uma "pátria-mãe", a Alemanha. Conforme Bairon (1991), é a construção dessa "pátria-mãe" que garante a possibilidade de dar unidade à comunidade local.

\section{Entre a recriação da Alemanha como "mãe-mítica" e a Alemanha do pós Guerra}

As comemorações realizadas no mês de julho, embora não tivessem o caráter oficial demarcando o festejo estadual, também foram destacadas pela imprensa da capital, ${ }^{8}$ 
tanto na parte de divulgação, quanto na cobertura dos acontecimentos.

$\mathrm{O}$ anúncio do feriado, na imprensa local e da capital, a solicitação de fechamento dos estabelecimentos comerciais e os convites para as festa, determinavam o clima festivo na cidade. No dia 25 de julho, que caiu numa sexta-feira, os festejos começaram cedo: às 4 horas da madrugada, em frente ao edifício da Intendência, uma banda de música tocou a alvorada. Às 6 e às 12 horas, os sinos de todas as igrejas tocaram. Também na manhã, em igrejas católica e evangélica, a data foi celebrada.

Conforme noticiou a imprensa, pessoas de vários distritos e localidades vizinhas visitaram a cidade para acompanhar os festejos em São Leopoldo e os hotéis estavam lotados (DUARTE, 1946).

À tarde, às 13h:30 minutos, reuniram-se na Praça da Estação, representantes de autoridades civis, vindas em trem especial de Porto Alegre, sociedades locais e das redondezas (Orpheu, Ginástica, Clube Bolão Separat, Sport Club Nacional) imprensa e população em geral. Desse local, percorreram $4 \mathrm{~km}$ ao local onde os primeiros imigrantes alemães foram estabelecidos, chegando ao destino, na sede da Feitoria do Linho Cânhamo, houve o pronunciamento de várias pessoas e também foi inaugurada uma placa comemorativa da chegada dos primeiros imigrantes e da realização do primeiro rito protestante no Rio Grande do Sul (DUARTE, 1946). O passado foi "convocado", não só nos discursos, mas também nos próprios rituais, permitindo a construção da "mãe mítica". Cabe salientar que o passado recente não foi pauta. Nas falas dessa oca- sião, não houve espaço para evocar a guerra finda. As comemorações comportam o caráter de serem seletivas (CANDAU, 2012), são feitas escolhas acerca do passado a ser comemorado. Assim, a festa apresenta-se como "[...] uma fala, uma memória e uma mensagem" (BRANDÃO, 1989. p. 8).

À noite ocorreu um momento cívico no salão da Sociedade Ginástica, onde novamente vários discursos foram proferidos. Nesse evento, a seleção do que seria referido incluía a situação da Alemanha no pós-guerra.

$\mathrm{O}$ ato festivo foi presidido por Martin Fischer, presidente da Sociedade daquela sociedade, que fez a primeira fala, em alemão:

Hoje é o dia historicamente consagrado e aqui é a cidade historicamente inaugurada, onde há 100 anos começou a colonização alemã que tanto contribuiu para a prosperidade e o florescer do Rio Grande do Sul. (...). Em nome e em missão dos leopoldenses presentes eu tenho a honra de cumprimentar em primeiro lugar o Cônsul alemão, Sr. Dr. Dehnhardt, que está em nosso meio como representante oficial do Reino Alemão, da terra que foi a pátria dos que, há 100 anos, colocaram seu pé em solo riograndense por primeiro, que é a pátria de tantos milhares que vieram depois destes, que é a pátria-mãe de todos nós. $O$ velho Reino Alemão em seu tamanho e beleza não o é mais. Deus usou pesadamente de sua mão sobre a velha, pobre (...) pátria, pela qual nossos corações batem mais fortemente hoje. Mas justo porque a Alemanha hoje está no chão, porque é tão desprezada e humilhada que nós nos declaramos com todo orgulho de nossa alma alemã a ela.

De coração aquecido nós confessamos: Nós amamos essa pobre e desgraçada terra de nossos pais. Sangue é mais consis- 
tente que água. Também a nós uma mãe alemã deu à luz. Com fidelidade alemã aos nossos irmãos de sangue lá na velha pátria, não queremos saber de dar essa terra e esse povo como perdido. A Alemanha não desaparecerá, não pode desaparecer, nunca. Nós acreditamos no país de nossos pais e nós confiamos no bom Deus lá em cima, que Ele salvará a terra alemã e o povo alemão da grande miséria de agora. ${ }^{9}$

Parece que o momento festivo não se coaduna com a menção direta ao conflito mundial, mas é da situação da Alemanha pós-guerra que Fischer refere por meio de elementos místicos: "Deus usou pesadamente de sua mão sobre a velha, pobre [...] pátria". Não cabia trazer para o plano concreto as circunstâncias efetivas do conflito num momento festivo. A referência a um passado grandioso "em seu tamanho e beleza não o é mais", a Alemanha injustiçada, bem como a necessidade esperança de reerguimento, são aspectos que estarão presentes em outras falas que rememoram a situação da Alemanha no Pós-Primeira Guerra.

Cabe lembrar, como mencionado anteriormente, que além de Fischer presidir uma sociedade que se constitui como reduto do germanismo ele próprio atuou num posto de comando na Primeira Guerra antes de ter vindo ao Brasil (GERTZ, 2002). A conjunção desses fatores por certo favoreceu colocar o tema em pauta na ocasião.

O discurso permite a identificação de um clima de entusiasmo e saudosismo presente nas comemorações da Sociedade Ginástica, bem como demonstra que as comemorações também serviram para reforçar, simbolicamente, os laços com a Alemanha.
As referências constantes ao "Nós" situa que o orador (locutor) tem como alocutório o público descendente de alemães, até porque Fischer usou o idioma alemão. Depois do discurso, Fischer em português, saudou as autoridades presentes o representante do Intendente em exercício, Oscar Stabel, o chefe político local, João Corrêa Ferreira da Silva, o representante do Intendente de Porto Alegre, Capitão Roberto Mathias Stoll e os demais convidados. Falou, agradecendo, o cônsul alemão e concluiu com um viva ao Brasil, ao qual, conforme o noticiado pela Deutsche Post, os presentes responderam com entusiasmo e, após, a orquestra tocou o hino nacional brasileiro, que foi ouvido de pé, pelos presentes.

A seguir, o Tenente Coronel Fausto de Azambuja Villanova também fez fala, em português. A tônica do discurso ressaltava "a importância do elemento alemão para o Brasil e para o Rio Grande do Sul" ${ }^{10}$ Villanova também mencionou seus sentimentos com relação à Alemanha de então:

Recordar aqui o muito que a colônia alemã tem feito em benefício de nossa grandeza material [...], é tarefa longa que escapa à minha competência e mesmo a história, a grande mestra da vida, a conselheira dos povos, registrou em documentos oficiais este ato de justiça, este preito de gratidão de nossa parte para com os dignos descendentes desta raça heróica, filhos desta Alemanha invejada e nunca vencida (DUARTE, 1946, p.137, 138)

Villanova atuava como diretor do Jornal local União, ligado aos republicanos de São Leopoldo, falou como locutor, de descendência lusa, ao mesmo tempo em que, enaltece os descendentes de alemães, se faz 
mais próximo do eleitor (alocutório) ao reforçar o discurso de Fischer, no sentido de uma Alemanha injustiçada.

Já o discurso do Conselheiro Municipal Roberto Matthias Stoll foi todo em português, e permeado com palavras "ardentemente entusiasmadas" sobre o povo alemão "como povo". Conforme a Deutsche Post, o orador terminou sua fala com um grande viva ao povo alemão. "Com explosivo entusiasmo, todos se levantaram das cadeiras e cantaram em pé 'Deutschland, Deutschland über alles' (Alemanha, Alemanha acima de tudo )". ${ }^{11}$ Depois, incluíram um quarto verso ao hino, que dizia:

Alemanha, Alemanha acima de tudo e na desgraça agora mais do que nunca!

Só na desgraça o amor pode mostrar se ele é forte e real (original); e assim deve continuar de geração para geração.

Alemanha, Alemanha acima de tudo e na desgraça agora mais do que nunca!"12

A festa prosseguiu com apresentações de ginástica e canções, cantadas por grupos da sociedade anfitriã. Como mantenedora da memória dos pioneiros ou como incentivadora da cultura alemã no período enfocado, a Sociedade Ginástica reavivava sentimentos e práticas restringidas no período anterior, com as ações nacionalizadoras do intendente Gabriel de Azambuja Fortuna.

$\mathrm{O}$ fato de os discursos que tematizaram o pós-guerra remeterem às mesmas questões indicam que o campo do memorável foi favorecido pela convergência entre representações (CANDAU, 2012). O conjunto da cena permite ver como o pertencimento é ressaltado a partir da unidade em torno da Alemanha "pobre e desgraçada", de onde se conclama o sentimento de solidariedade. A coesão do grupo é reforçada a partir do desejo de reerguimento da pátria mãe. Para Gertz (1987), o sentimento de derrota do pós-guerra, motivou "um desejo de reerguimento" entre os germanistas. Sem dúvida, as comemorações do 25 de julho foram um espaço de manifestação da germanidade, contudo, é importante frisar a necessidade de cautela ao analisar como se dá esta presença e perguntar-se se a festa como um todo pode ser traduzida como sua expressão (WEBER, 2004).

Convém sublinhar que na ocasião das celebrações na Casa da Feitoria, alguns dos oradores foram os mesmos do evento realizado na Sociedade Ginástica, esse é o caso de Martin Fischer e de Fausto Azambuja Villanova. No entanto, naquele local não se tematizou a situação da Alemanha no pós-guerra.

As comemorações oficiais, que ocorreram no mês de setembro, foram também perpassadas por discursos, cujo tema era centrado nos agradecimentos aos pioneiros, na laboriosidade dos alemães e seus descendentes, na importância do elemento alemão para o Rio Grande do Sul e o Brasil. A festa oficial foi também apoteótica, e caracterizou-se por ser mais ampla, com divertimento para todos os segmentos sociais da cidade, diferentemente da festa do 25 de julho, que foi principalmente "dos alemães".

Nas dependências de outro clube fundado por alemães no Século XIX, na cidade de Porto Alegre, a Sociedade Leopoldina, o 
momento de comemoração do Centenário da imigração alemã, também foi oportuno para referir a Alemanha do pós- guerra. Dentre as autoridades presentes no ato estavam o Presidente do Estado, Borges de Medeiros, o intendente municipal, José Montaury, bem como o cônsul da Alemanha, Hentique Daenhardt (DUARTE, 1946). Um dos oradores do evento foi Alberto Bins, industrial e homem público, membro de associações culturais rio-grandenses de origem alemã, então, ocupando o cargo de deputado estadual, fala enquanto representante da Liga das Sociedades Germânicas (DUARTE, 1946). Depois de abordar a história da colonização e o significado do centenário, ressaltou na parte final do discurso:

Esquecer, porém, a Alemanha, pátria que nos enviou 57.000 dos seus filhos representaria uma indesculpável falta, essa Alemanha que nos legou e nos forneceu inestimáveis valores culturais [...]. É por isso que, nós, os brasileiros descendentes desses 57.000 trabalhadores, desejamos, de todo o coração, que ela ressurja, de pronto, e volte a ocupar o seu lugar sob o sol, pelo direito que lhe confere o patriotismo [...] fazendo-lhe justiça, possa, dentro em breve, anunciar que ela não foi a única culpada na conflagração mundial (DUARTE, 1946, p. 213-214).

Bins, filho de imigrantes alemães, tomou a palavra enquanto representante de imigrantes e descendentes de alemães. Mesmo no ato festivo, referendou que era preciso lembrar-se de não esquecer a situação de então da Alemanha. Tematizou um ponto crucial que foi alvo de debate entre os historiadores alemães após a Primeira Guerra mundial, qual seja, o tema da "mentira sobre a responsabilidade pela guerra" (MUHLACK in EBERHARD, 2013. p. 28). Ao passo que isso ocorre no cenário da produção historiográfica alemã, na França:

[...] a corporação dos historiadores franceses foi praticamente intimada, mal foi assinado o armistício, a "demonstrar" a responsabilidade unilateral da Alemanha wilhelmiana no desencadeamento das hostilidades em 1914, que fora afirmada no artigo 231 do Tratado de Versalhes e por isso mesmo justificava o pagamento das reparações (AZÉMA, 1996. p. 407).

Frente a essa situação o dever de memória estava posto aos descendentes de imigrantes alemães, evocado mais uma vez, num espaço privilegiado de uma sociedade representativa dos alemães.

Ao se estudar as comemorações oficiais realizadas em setembro não se localizaram fontes que indicassem discursos que remetam à Primeira Guerra, o que pode ser relacionado com a diferença do caráter dessas comemorações. Enquanto os festejos de setembro se constituíram em oportunidade para os descendentes de alemães se mostrarem aos "outros", identificando como queriam ser vistos, valendo-se para tal, do passado e da promessa de futuro. Nesse cenário não havia espaço para abordar o tema da Alemanha do pós-guerra que foi referido em julho. Nos festejos desse mês, o tema da integração não esteve com tanta intensidade em pauta, tal como em setembro, de certo modo não era preciso que o descendente de alemães mostrasse quem era, bastava apenas que ele festejasse a si próprio apoiando-se, sobretudo em seu passado, nas comemorações que tiveram mais cunho local. No entanto, cabe lembrar, que mesmo em julho o tema da guerra só foi referido em evento ocorrido em espaço privado, com audiência 
mais restrita, onde o público ouvinte talvez fosse mais unânime na concordância com aquele que articula o discurso.

\section{Considerações finais}

As fontes perscrutadas acerca das comemorações do Centenário da imigração alemã no Rio Grande do Sul, mais especificamente em São Leopoldo, apontaram para a singularidade do tema da Primeira Guerra Mundial no evento. Pode-se inferir que o não falar sobre o mesmo, não implica esquecimento, mas antes demonstra que certamente era embaraçoso, pelo contexto político, somado ao fato de que se tratava de eventos festivos. Mesmo assim, houve espaço para abordá-lo. As poucas referências à crise da Alemanha, assim como as inúmeras referências que fortaleciam a Alemanha enquanto "mãe mítica", constituem-se em elemento unificador, servindo como fator para justificar a união dos descendentes. De modo que, apesar da Alemanha estar em crise, ela continua sendo alçada como referência que atua na recriação da "mãe-mítica". Tal como nos discurso que falavam sobre a Alemanha a partir do encantamento pelo passado, a adesão afetiva, o reforço do pertencimento se mantém na evocação da Alemanha injustiçada que faz com que se manifeste um senso de solidariedade em torno da Alemanha derrotada. Ou seja, a Alemanha foi enaltecida tanto nos discursos em que se remete ao passado glorioso, quanto, quando se remete a um presente recente "inglório".

Apesar de o momento ser comemorativo, houve espaço para rememorar a guerra, embora em espaço restrito. Os discursos ma- nifestados na Sociedade Ginástica de São Leopoldo e na Sociedade Leopoldina de Porto Alegre, foram condicionados por essas mesmas instituições. Possivelmente, a audiência, os interlocutores seriam mais receptivos à oratória. De outro modo, os resquícios do contexto pós Perigo alemão, as desconfianças e ressentimentos, provavelmente, foram fatores importantes para delimitar os espaços de manifestações que remetessem ao conflito.

\section{Abstract}

This article focuses on the Centenary Celebrations of German immigrations in Rio Grande do Sul state, more specifically, in São Leopoldo city, considering the context after the First World War and the remains of the "German's danger". This paper analyses the speeches made on the German's immigration Centenary through documental research. These facts identify that the presence of the "motherland" Germany is not only effective in remote memories of the earlier immigrants, but also considering Germany after the World War.

Keywords: Centenary of German immigration. First World War. São Leopoldo city.

\section{Resumen}

El presente artículo enfoca las conmemoraciones del Centenario de la inmigración alemana en Rio Grande do Sul, más específicamente, en São Leopoldo, considerando el contexto de pos Primera Guerra Mundial y de los resquicios del "Peligro Alemán". A través de investigación documental analiza discursos 
proferidos en los rituales conmemorativos al Centenario de la inmigración alemana. Identifica, en estos rituales, que la presencia de la "patria madre" Alemania, no se efectiva solamente en recuerdos remotos de los primeros inmigrantes, sino también, considerando la Alemania de posguerra.

Palabras clave: Centenario de la inmigración alemana. Primera Guerra Mundial. São Leopoldo.

\section{Notas}

1 MAGALHÃES (1988) refere-se às sanções do Tratado de Versalhes para os alemães.

2 O "perigo alemão" serve para designar a campanha que se estendeu de meados do século XIX até a Primeira Guerra, frente a supostos interesses imperialistas da Alemanha (GERTZ, 1991).

3 Conforme Magalhães, "o antigermanismo e a guerra causaram um certo efeito de destilação entre os segmentos de origem germânica (...)." MAGALHÄES, 1988, p. 99.

4 Frente a isto, situamo-nos numa postura acordante com o quadro epistemológico da análise de discurso, entendendo a linguagem em seu funcionamento. Ver ORLANDI, 1996.

5 Muitos clubes de Tiro durante a Primeira Guerra Mundial transformaram-se em Tiros de Guerra.

6 DEUTSCHE POST, São Leopoldo, 19 de Julho de 1924, p.5.

7 Locutor e alocutório são funções enunciativas do sujeito falante que dão indicativos da função social que o "eu" do discurso assume, ambos são categorias que permitem caracterizar a polifonia da enunciação. O locutor é representado pelo "eu" falante do discurso e o alocutório é o "tu" do discurso (ORLANDI, 1996. p. 61 -62).

8 Correio do Povo e A Federação.

9 Deutsche Post. São Leopoldo, 26 de julho de 1924, p. 2.

10 Deutsche Post, São Leopoldo, 26 de julho de 1924, p. 3.

11 Deutsche Post, São Leopoldo, 26 de julho de 1924, p. 3.

12 Deutsche Post, São Leopoldo, 26 de julho de 1924, p. 3.

\section{Referências}

ALBUQUERQUE JÚNIOR, Durval Muniz de. A dimensão retórica da historiografia. In: PINSKY, Carla; LUCA, Carla Regina de. (Orgs.) O historiador e suas fontes. São Paulo: Contexto, 2009.

AZÉMA, Jean Pierre. A guerra. In: RÉMOND, René (Org.) Por uma história política. Rio de Janeiro: Editora UFRJ, 1996.

BAIRON, Sérgio. História palinódica: significações culturais de uma regionalidade teuto-brasileira. São Paulo. 1991. Tese (Doutorado em História) - Faculdade de Filosofia, Letras e Ciências Humanas, USP.

BAIRON, Sérgio. O fantasma da unidade cultural na metáfora palinódica do brasileiro alemão. Revista de História. São Paulo, n. 129-131, ago.-dez./93 a ago.-dez./94.

BRANDÃO, Carlos Rodrigues. A cultura na rua. São Paulo: Papirus, 1989.

CANDAU, Joël. Memória e identidade. São Paulo: Contexto, 2012.

DREHER, Martin N. Igreja e germanidade. São Leopoldo: Sinodal, 1984.

DUARTE, Eduardo. O centenário da colonização alemã no Rio Grande do Sul: 1824-1924. Porto Alegre, Tipografia do Centro, 1946.

GERTZ, René E. O fascismo no sul do Brasil. Porto Alegre, Mercado Aberto, 1987

. O perigo alemão. Porto Alegre: Editora da Universidade/UFRGS, 1991.

. O aviador e o carroceiro: política, etnia e religião no Rio Grande do Sul dos anos 1920. Porto Alegre: Edipucrs, 2002.

MAGALHÃES, Marionilde Brepohl de. Pangermanismo e nazismo: a trajetória alemã rumo ao Brasil. Campinas, São Paulo: Ed. da Unicamp/Fapesp, 1988. 
MUHLACK, Ulrich in EBERHARD, Renata Maria Pistilli. Sobre tradição e inovação na ciência histórica alemã: entrevista com Ulrich Muhlack. Revista História da historiografia. Ouro Preto, n. 12, p. 13-33, ago. 2013.

NORA, Pierre. Entre a memória e a história: a problemática dos lugares. Projeto História. São Paulo, v. 10, n. 10. p. 7-28, dez. 1993.

ORLANDI, Eni Pulcinelli. Discurso e leitura. São Paulo/Campinas: Cortez/Ed. UNICAMP, 1996.

PELLANDA, Ernesto (Org.). A colonização germânica no Rio Grande do Sul: trabalho organizado de ordem do governo do estado em homenagem a colônia alemã em seu centenário. Repartição de Estatística do Estado do Rio Grande do Sul. Porto Alegre, Oficinas Graf. Livraria do Globo-Barcellos, Bertaso \& Cia, 1925.

PESAVENTO. Sandra J. A invenção da sociedade gaúcha. Ensaios FEE, Porto Alegre, v. 14, n. 2, p. 383-396, 1993.

RAMOS, Eloisa H. C. da Luz. O teatro da sociabilidade: um estudo dos clubes sociais como espaços de representação das elites urbanas alemãs e teuto-brasileiras: S. Leopoldo, 1850/1930. Porto Alegre, 2000. Tese (Doutorado em História) - Instituto de Filosofia e Ciências Humanas, UFRGS.

SEYFERTH, Giralda. A identidade teuto-brasileira numa perspectiva histórica. In: $\mathrm{MAUCH}$, Cláudia; VASCONCELLOS, Naira (Orgs.). Os alemães no sul do Brasil: cultura, etnicidade e história. Canoas: Ed. Ulbra, 1994. p. 11-27.

A representação do "trabalho alemão" na ideologia étnica teuto-brasileira. Boletim do Museu Nacional. Rio de Janeiro, v. 37, n. 37, p. 1-33, 20 out. 1982.

A assimilação dos imigrantes como questão nacional. Mana. Rio de Janeiro; (Museu Nacional/UFRJ), v. 3, n. 1, p. 95-131, 1997.
WEBER, Roswithia. As comemorações da imigração alemã no Rio Grande do Sul: o "25 de Julho" em São Leopoldo, 1924/1949. Novo Hamburgo: Feevale, 2004. 